\title{
A Generational War Is Launched with The Birth of Ok Boomer in The Digital Age
}

\author{
Young Joon Lim ${ }^{1 *}$, Jennifer Lemanski ${ }^{2}$ \\ ${ }^{1,2}$ Department of Communication, University of Texas Rio Grande Valley, Texas, USA \\ Austin, TX 78712, Amerika Serikat \\ Email: young.lim@utrgv.edu \\ Email: jennifer.lemanski@utrgv.edu
}

\begin{abstract}
This study examined the recent virality of "Ok Boomer" in the United States. The term Ok Boomer gained overnight momentum in the public sphere as the symbol of a generational war. While previous research has primarily examined racial and gender tensions, this study introduced a new phenomenon of the generational conflict between "Ok Boomers" and "Baby Boomers," in which social media-originated the term Ok Boomer and traditional media diffused it with framed meaning. Diffusion of Innovation theory was used to understand better how "Ok Boomer" as a catchphrase, hashtag, noun cluster, or trend resulted in attracting a massive amount of media and public attention. Relying on Node $X L$, Google Trends, and Nexus Nexis for data gathering and analyses, this study categorized four themes for a word or an idea as an innovation to be publicly acknowledged: collaboration of social media and traditional media, public figures' involvement for debate; contentious social issues, and media-framed agenda. In sum, this study argues that the term Ok Boomer symbolizes the advent of a generational war in society in line with the long-standing race and gender wars in media coverage.
\end{abstract}

Keywords: ok Boomer, baby boomer, diffusion, generational war, hashtag

\begin{abstract}
Abstrak
Studi ini menguji viralitas "Ok Boomer" yang baru-baru ini berkembang di Amerika Serikat. Istilah "Ok Boomer" mendapatkan momentum di ruang publik sebagai simbol perang generasi. Sementara penelitian sebelumnya banyak meneliti ketegangan antar ras dan gender, penelitian ini memperkenalkan fenomena baru dari konflik generasi antara "Ok Boomers" dan "Baby Boomers". Media sosial memunculkan istilah "Ok Boomer" sementara media tradisional menyebarkannya dengan berbagai makna. Teori Difusi Inovasi digunakan untuk lebih memahami bagaimana "Ok Boomer" sebagai slogan, tagar, kluster kata benda, atau tren menarik bagi sejumlah besar media dan mendapatkan perhatian publik. Mengandalkan Node XL, Google Trends, dan Nexus Nexis untuk pengumpulan dan analisis data, penelitian ini mengkategorikan empat tema untuk satu kata, atau sebuah ide sebagai inovasi yang harus diakui publik: kolaborasi media sosial dan media tradisional, keterlibatan tokoh masyarakat untuk perdebatan; masalah sosial yang konfrontatif, dan agenda berbingkai media. Singkatnya, penelitian ini berpendapat bahwa istilah Ok Boomer melambangkan munculnya perang generasi di masyarakat sejalan dengan ras lama dan perang gender dalam liputan media.
\end{abstract}

Kata Kunci: ok boomer, baby boomer, difusi, perang generasi, hashtag 
Submitted: 2020-01-28; Accepted: 2020-03-13; Published: 2020-04-23

*Corresponding author: Email: young.lim@utrgv.edu

\section{INTRODUCTION}

Communication is fundamental to human existence. There is a link between communication and quality of life (Srivastava 2012). Human potential develops through close, supportive, and interpersonal communication. Human beings are, in essence, relational and thus need contact with others. During interpersonal communication, people make contact with others as persons, thus reinforcing their humanness (Helsper and Enyon 2009). Mutual communication means recognizing another human being's humanness in a shared world. Meaningful interpersonal communication looks at how two people interact as a dyad treating each other as unique and irreplaceable individuals. In other words, they impact each other's lives (Venter 2017). Time magazine announced in December 2019 that Greta Thunberg, the Swedish teen activist who became the voice of a new emerging generation concerned about climate change, is the magazine's 2019 Person of the Year. Thunberg, 16, is the youngest person to be named with the accolade, which lauded her tremendous impact on "the news and the world". Influenced by Thunberg's media-attention-grabbing activities, U.S. media covered her every move and word by portraying her as the poster child of new values for a new generation that integrates millennials, and Generation Z. Following Thunberg's rising fame, a new conceptual term that combines millennials and Generation $\mathrm{Z}$ was introduced to the public in the social media community. The term is $O k$ Boomer, which went viral online first. As U.S. mainstream media, such as the New York Times, CNN, NBC, and the Washington Post, popularized the conceptual term of Ok Boomer with their initial coverage in late 2019, the reactions of the American public appeared to have constructed two divisive and hostile groups of generations: Young vs. Old. The former is represented by the new generation of "Ok Boomer," and the latter is represented by the old generation of "Baby Boomer" (Parment 2013).

Baby Boomers America born between 1946 and 1964, represent the largest generation of Americans (Iii 2016). Australian study may have broader applicability in indicating the limits to consumption among the boomer generation boomer generation's perception of the boomers as the "lucky generation", happily pioneering a trend towards the end of retirement, is simplistic and misleading. The popular idea that baby boomers are the "generation that will never retire" is conditioned very much by the expectations of wealthier boomers. The traditional notion of retirement is now inspired only by the working class. The reality for most 


\section{Lim: A GenerationalWarlsLaunched \\ with TheBirth of OkBoomerinThe}

Digital Age

of these lower-income earners is worry about how they will fund their retirement, and this is leading them to delay retirement (Phillipson, Chris, Leach, Money, and Biggs 2017).

The baby boomers are not a cohesive group. Instead, that generation comprised a series of cohorts whose life experiences have differed due, in part, to the sociohistorical context in which they were raised (Winston, Barnes, and Winston 2008). In this research context, Generation Y and the Baby Boomer generation are the preferred terms, and their characteristics are used generically. The focus, however, is on how they communicate rather than on all the general characteristics of the specific generation. These generations have unique ways of communicating - Baby Boomers have mastered using some digital devices but are not comfortable using only $\mathrm{CMC}$ for interpersonal communication. At the same time, Generation Y is comfortable with CMC (Krohn 2004). Baby Boomers communicate primarily using face-to-face communication, telephone conversations, and email. They will seldom use blogs, wikis, social networking sites, and texting or instant messaging in more formal situations, such as in the work context (Heng and Yazdanifard 2013). They rely on face-to-face communication, where body language and non-verbal cues are essential. Older generations are using CMC more often, but mainly through emails or short messages on mobile phones. Gradually, however, they are moving towards using other social and digital media, but many of the older members of this generation are still uncomfortable with CMC (Turnbull 2010). According to Glass (Glass 2007), differences, especially in their choice of communication media, can cause conflict between the two generations. Most Baby Boomers have a problem with how Generation Y uses technology for work, play, and studies. At the same time, Generation Y sees Baby Boomers as being resistant to new technology and change.

Whereas the generation of "Ok Boomer" is a relatively new concept and has been gaining public recognition, it is not sure whether the term Ok Boomer becomes a socially widespread concept or norm that could make it into print, such baby boomers and millennials. As human language grows with social issues and trends in a societal setting, all new words are created through the procedures of being recognized, used, and shared by societal human beings (Bodle 2016). The media, as a means of the communication channel, traditionally play a significant role in creating and disseminating new words and concepts to the public (Ross, Todd, and 
Saedi 2015). More recently, social media has shared such a traditional media role in the digital age. OK Boomer as a noun cluster was first created in the social media community mid-2019. The mainstream media recognized and reported the rapid and comprehensive virality of the new character-defining term for millennials and Generation Z in late 2019. In the media coverage, the generation of "Ok Boomer" is linked with rebellious characteristics of social and global issues, including global warming or climate change, social injustice, environmental pollution, and gender discrimination (Gaetan 2019). Thunberg has been at the center of Ok Boomers' characteristics in media portrayal since she made her fiery speech to the United Nations in September 2019, warning of the world's end because of climate change. Her overnight fame was partly due to President Donald Trump's response to her speech, sarcastically tweeting: "She seems like a delighted young girl looking forward to a bright and wonderful future. So nice to see!".

President Trump's tweet sparked heavy media coverage of Thunberg and her symbolic status for the new generation of "OK Boomer." There are two sides of groups that support Thunberg's activism or criticize her provocative work. The divisive opinions have led to a generational confrontation between "Ok Boomers" and "Baby Boomers" in social media and traditional media. (Riederer 2019) argued that it was the emerging genesis of a generational conflict, represented by President Trump for baby boomers and the 16-year-old activist as the poster child for "OK Boomer." At the crux of the new generational war as of late 2019, this study turns to the theory of Diffusion of Innovations (DOI) to explore the process of giving birth to a new social phenomenon that has a tremendous impact on the U.S. public, especially concerning exploring the advent of a generational concept of "Ok Boomer," created and produced by both online and offline media environments (Choudhury, Lin, Sundaram, Candan, Xie, and Kelliher 2010). The theory of Diffusion of Innovation (DOI), since the publication of Everett Rogers' (Rogers 1962) seminal text, demonstrates the path of how people adopt innovation in a specific social system. The critical term diffusion is "the process in which an innovation is communicated through specific channels over time among the members of a social system. Diffusion of innovations describes the diffusion process of a new idea, technology, or product through a social network. The rapid developments of communication, transportation technologies, and social networking services make connections between people denser and more complex. So the diffusion mechanism of innovations is becoming more and more complex 


\section{Lim: A GenerationalWarlsLaunched \\ with TheBirth of OkBoomerinThe}

Digit a I Age

(Choi and Yu 2020). From a communication perspective, DOI illustrates how a product or an idea gains momentum until the public recognizes it through a specific process invigorated by the media. Similarly, Roger's innovation diffusion model has four essential features related to the widespread adoption of technologies (Rogers 2010). The four features are compatibility (an innovation is considered to be consistent with the needs of potential adopters), complexity (a complicated innovation negatively affects its rate of adoption), trialability (an innovation can be experimented upon for a limited time), and observability (an innovation leads to an easy understanding and observing for adopters).

Researchers have found that people who adopt a specific technology or ideologic innovation early show different characteristics than people who adopt it later (Atkin, Hunt, and Lin 2015). Marketers, advertisers, and public relations practitioners must capitalize on such characteristics of adopters at different stages to promote a product or an idea. The adoption of innovation varies throughout the product life cycle, and adopters can be categorized into the five groups of target audiences (Rogers 1962) as follows:

Innovators - Be the first to try the innovation by taking risks.

Early Adopters - Be opinion leaders spreading their evaluation of the innovation.

Early Majority - Be adopters of the innovation before the average person.

Late Majority - Adopt an innovation after the majority has tried it.

Laggards - Be skeptical of the innovation by upholding tradition.

While the early developmental phase of DOI focused on the application to the effects of mass communication such as television, newspapers, and radio, more current researchers are finding DOI applicable to social media's innovation to a target audience (Bianchi, Benedetto, Franzò, and Frattini 2017). For example, Archibald and Clark (Archibald and Clark 2014) pointed out that Twitter, as an innovative social media platform offers a swiftly responsive channel to strategic communicators and their target audience who meet online with tailored themes and mutually reciprocal interests. Another study argued that Twitter, based on the practical application of DOI, is easy to use, visualizable to understand, and simple to execute for the message sender and the receiver (Loukis, Charalabidis, and Androutsopoulou 2017). Among several social media platforms, Twitter provides a public forum for different market systems that move beyond the traditional hierarchical structure of government-driven autocracy (Wagner and Gainous 
2009). Social media is a virtual space for people to discuss narrative policy innovations. As Twitter has shifted its direction toward forming and debating social and political agendas from a general online communication forum, mainly since the 2016 U.S. presidential election, it serves as a powerful social media platform for policy advocates who wish to grow their supporters (Hemsley, Garcia-Murillo, and Macinnes 2018). In fact, (Oehmichen, Hua, Lopez, MolinaSolana, GomezRomero, and Guo 2019) found that Twitter is a more politically motivated social media platform to influence the target audience, promote advocacy, and diffuse political ideology. In sum, Twitter in the digital age plays a dominant role in diffusing persuasive and innovative information or messages to the target audience in hopes of creating and diffusing innovative ideas and amassing political and social support.

The novelty of this research, departing from previous research and the theory of DOI, this study argues that little communication scholarship has examined the pathway for a specific term as a noun cluster to become a familiar concept and even a popular word in both online and offline media environments. Therefore, the following questions are posed, based on the case of the sensational overnight term of $\mathrm{Ok}$ Boomer in the U.S. society:

R.Q. 1: In what communicative ways does "Ok Boomer" become recognized as a new generation?

R.Q. 2: In what communicative ways does "Ok Boomer" symbolize a new generational conflict?

\section{METHODS}

Twitter provides speed and informative content with a simple interface, which results in low complexity and a higher rate of adoption (Hall, Tinati, and Jennings 2018). Following ample evidence to show how the diffusion of innovation theory can be applied to Twitter's high adoption rate, this study constructs two datasets by employing toolkits by Node XL for Twitter data and LexisNexis for media data. The datasets comprise 5,175 tweets from the hashtag \#Ok Boomer and 24 news 


\section{Lim: A GenerationalWarlsLaunched \\ with TheBirth of OkBoomerinThe}

Digital Age

articles from major U.S. news outlets that recognized the term Ok Boomer as a new social phenomenon in their first article publication. The hashtag was included because hashtags with any combination of characters promote "trend" and attract more individual users to a discussion (Zhang, Zheng, and Pang 2018). Whereas the Twitter data were collected from November 3 to November 13, when the term $O k$ Boomer went viral online, the media data were collected from October 29, 2019, to November 15, 2019. During the period, traditional U.S. media recognized "Ok Boomer" and portrayed it as a provocative phenomenon for a generational war.

Researchers analyzed tweets and news articles using the constant comparison method using qualitative content coding schemes based on a suggested set of Twitter characteristics. Twitter coding aims to determine whether content might go viral, including humor, novelty, resonance, and quality in categorization (Schiavone and Simoni 2019). Among over 5,000 tweets, the researchers randomly chose 500 tweets to categorize their characteristics for the virality of \#OkBoomer. In addition, this study investigated the Top 30 most influential Twitter accounts that sparked the emergence of the Ok Boomer. The 24 major news articles about the term $O k$ Boomer are also analyzed to identify any specific paths for the new word as a noun cluster to gain overnight popularity by the broad spectrum of the public, who got into the disruptive generational conflict unlike traditional conflicts such race and gender.

\section{RESULTS AND DISCUSSION}

The content of Twitter virality themes. RQ1 explored how the term $O k$ Boomer was socially recognized and widely accepted by the public as a new generation. Two themes were identified: (1) Twitter virality and (2) traditional media's preference to use social media as a news source.

RQ1: theme 1 - Twitter virality

Although the exact origin of the term Ok Boomer is currently unknown, this study found that "OK, Boomer" was first popularly born on the lip-syncing app, 
Tik Tok, on October 15, 2019, by Peter Kuli, turned the term a catchphrase meme on a rap song that mocked and debased baby boomers' advice for millennials and Generation Z (see https://www.tiktok.com/music/Ok-Boomer-byPeter-Kuli6753366955043883781). Since then, the two-word catchphrase was spread overnight via Twitter with the hashtag \#Ok Boomer, which catapulted to the top 10 Twitter trends in the United States on November 6, 2019. More critically, \#Ok Boomer dominated the online and offline media on November 12, 2019, when a senior executive of AARP, the American Association of Retired Persons, mocked the \#Ok Boomer catchphrase by saying, "We are the people that have all. In response, the hashtag \#Ok Boomer sparked vigorous Twitter debate from younger and older generations. The Twitter debate, led by social media influencers, served as the tipping point for a new generational war (Taneja, Wu, and Edgerly 2018). The popularity of social media may have also contributed to more commonalities than differences in patterns of news usage between generations. Although counterintuitive given the prevalent notion about the millennials' characteristic dependence on SNS, when analyzed as part of their news usage networks, Facebook and Twitter figure among the essential sites for both cohorts, a finding which supports our infrastructural expectation. (Webster

2006) Figure 1 visually identifies the Twitter influencers regarding the virality of \#Ok Boomer.

Figure 1. 


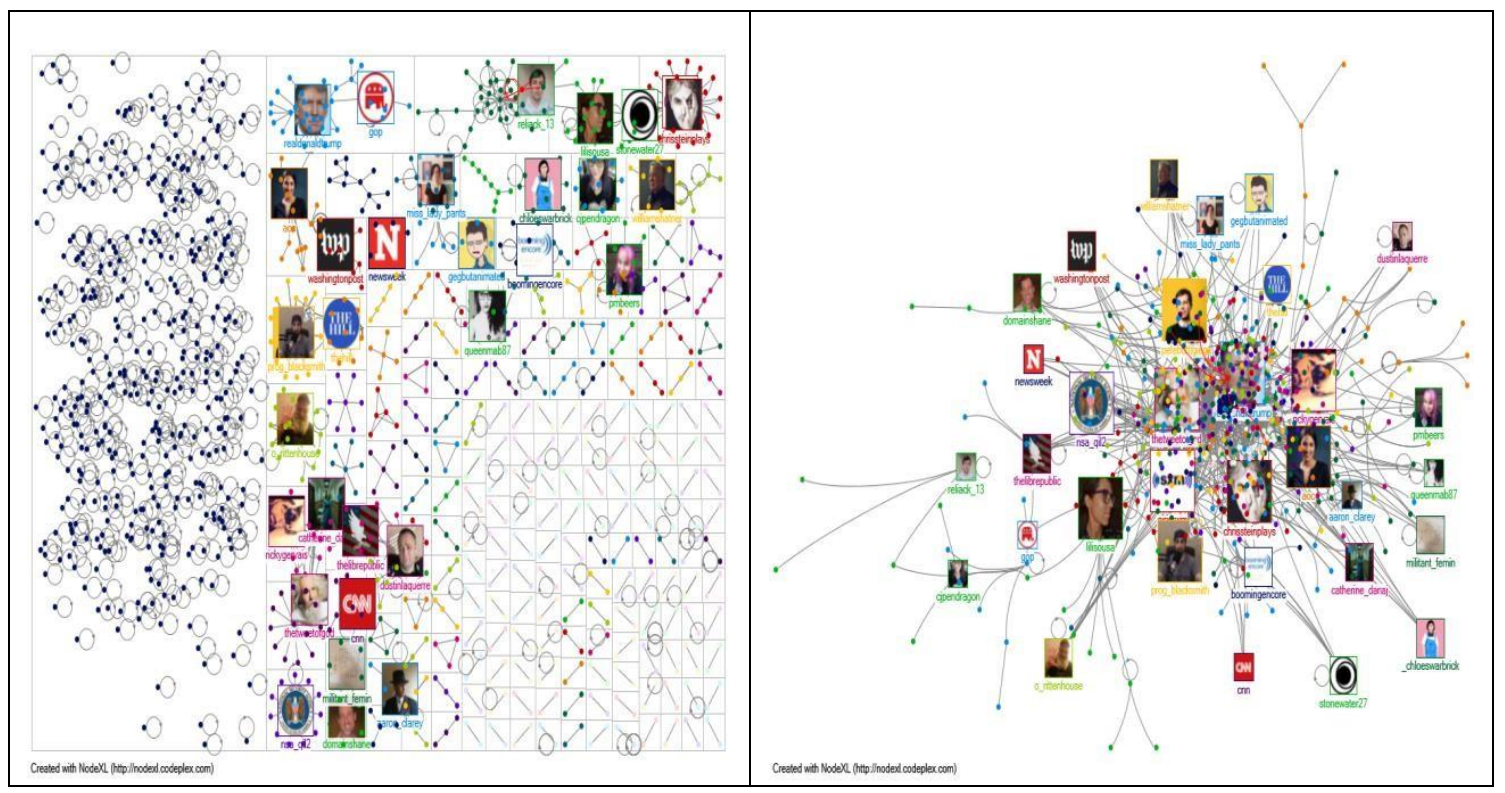

The Visualization of Twitter Influencers by Layouts

Figure 1 out of more than 5,000 tweets illustrates that politicians such as President Trump, Representative Alexandria Ocasio-Cortez, 2020 U.S. Democratic presidential candidate Pete Buttigieg and major U.S. news outlets such as the Washington Post, CNN, and Newsweek are the Top 30 influencers on the \#Ok Boomer virality. Politicians and news agencies still have the power to form and popularize a new social term, even in the digital age.

RQ1: theme 2 - traditional media's preference to use social media as a news source.

The first popularity on Tik Tok's "Ok Boomer" caught the attention of the New York Times, which first published an in-depth article on the phenomenon of "Ok Boomer" on October 29 (Lorenz 2019). Other major U.S. news outlets paid attention to it. They used social media \#Ok Boomer posts as their primary news source to report its virality between October 30 and November 13, 2019, including the Washington Post, CNN, CBS News, NBC News, USA Today, and so on. Google Trends demonstrates that the search interest for "Ok Boomer" received a score of 0 until October 26, but it took off to a score of 23 on November 2 and received a score of 100 on November 9, "the peak popularity for the term". In less than three weeks, from October 15 to November 3, the term $O k$

Boomer emerged as one of the essential terms for the public to recognize as an 
ongoing glossary for 2019 life online, according to the Washington Post (Ohlheiser 2019).

R.Q. 2 sought a path to identify how a new term, with its birth, was likened to a specific symbol of meaning in society. This study found that the special meaning of a word or words can be manufactured and framed by the media, which have the power to circulate tailored and inferred information to the public. The major media outlets played a primary role in distributing the information of "Ok Boomer" while setting a national agenda to energize the public's attention to the specific conflict between the young and old generations. Furthermore, the media presented Ok Boomer as a contentious public issue based on the narrative paradigm of why the younger generation antagonizes the old generation. As a result, the public understood the two-word catchphrase, "Ok Boomer," as the symbolic meaning of generational war, which implies conflict and animosity between the two generations. The media pushed such a hostile meaning via their reports. Below is some evidence of how the media portrayed "Ok Boomer":

- Now it is war: Gen $\mathrm{Z}$ has finally snapped over climate change and financial inequality (New York Times).

- In case you had not noticed, the Generation Wars are on (Washington Post).

- OK, Boomer. Ready for a trademark application war? (CNN)

- Gen $\mathrm{Z}$ and millennial's aim at baby boomers are fueling a generational war (NBC news)

- Now it is war (The Guardian)

- OK, Boomer: How a viral catchphrase is reshaping generational war (CBS news)

- The generational war shows itself in politics and the workforce (The Hill) Other online news outlets also showed the exact portrayal of the term: The generation war: 'Okay, boomer' is trash-talking these days (Arkansas Gazette); The Phrase 'OK, Boomer' Has Now Created an All-Out Generational War (Inc News); and 'OK Boomer': The latest offensive weapon in generational warfare (The New Daily). From the results of the research questions, "Ok Boomer" was born and publicly acknowledged by the collaborative work of social media and traditional media with the aid of media-diffused implications.

The social norm of ok Boomer in public. A word is often meant to be taken for sarcasm, so Ok means "never okay" for the Ok Boomer generation. Ok, Boomer gained overnight popularity thanks to the rise of simultaneous issues and the involvement of public figures in late 2019, including Greta Thunberg's speech, President Trump's mocking tweet on Thunberg, younger generation's criticism of 
baby boomers' out-of-touch or materialistic lifestyles, and climate change. More importantly, the term $\mathrm{Ok}$ Boomer is portrayed as a stimulus to wage a generational war in the media coverage. Some sufferings of millennials and Generation $\mathrm{Z}$ are real. For example, the younger generation struggles to pay high debts for college degrees, grab low opportunities to get decent jobs and find environmentally clean places to live (Lee, Lee, and Kim 2019). In particular, younger Americans are concerned about the future burdens of the baby boomer generation, expecting to pay more social obligations and liabilities while living on the polluted earth.

As Lorenz argued (Lorenz 2019) and Google Trends showed, the term Ok Boomer exploded from several social media posts. Online and offline media molded the term into a generational war, initiated by the younger generation who showed animosity against baby boomers who have created social policies to support their economic establishment. The birth of "Ok Boomer" as a catchphrase, hashtag, noun cluster, or trend results in attracting a massive amount of media and public attention. The term $O k$ Boomer has been in public knowledge. Much of the academic literature by scholars have yet to be developed soon in the conceptualization or theoretical framework structure. Marketers and politicians will introduce more practical analyses and communication experts to alleviate the admonishment of millennials (ages 25-39) and Generation Z (24 and under) toward older people. The media identified the birth of "Ok Boomer" as the advent of a generational war, which never happened in the United States.

In contrast, race and gender wars have a long-standing history in U.S. media coverage. This study followed the trail of the new term Ok Boomer, which entailed how it gained overnight popularity, including both young and old generations. The theory of DOI guided this study to elaborate on the birth and polarity of "Ok Boomer," in which social and traditional media played a pivotal role in creating and diffusing new ideas or concepts. Ok, Boomer can be identified as a catchphrase, Twitter hashtag, or trend in late 2019 for American society. However, this study argues that the viral diffusion of social media by influencers and the framing of traditional media by opinion leaders can give birth to a new word or term with social meaning.

The case of "Ok Boomer" clearly exemplified this. This study also shows that social and traditional media collaboration is likely to make an idea or a concept go viral 


\section{2| TheJournalof SocietyandMedia 4(1)}

in the digital age, in which new words can wax and wane online in a few days. The term Ok Boomer will not be easily forgotten; instead, it will spark more social debate as it has been acknowledged as a generational war to the public. More importantly, this study demonstrates that gaining momentum on innovation still requires traditional media coverage from television and newspapers. The media still have the capability of setting public agendas, framing issues, and diffusing information to the public.

\section{CONCLUSION}

Overall, the social impact and the meaning of "Ok Boomer" need more indepth studies that connect the link between different social variables, including political, cultural, and legal paradigms. Providing a usable framework to investigate the emergence of the OK Boomer generation is an ongoing challenge for many nations with a capitalist economy. Fortunately, because of open Twitter and online media data, this study can identify and illustrate the new generation of "OK Boomers." This can guide further research to predict how the new generation activates social changes for a cleaner environment and fair opportunity. 


\section{REFERENCES}

Archibald, M. and Clark, A. 2014. "Twitter and Nursing Research: How Diffusion of Innovation Theory Can Help Uptake.” Journal of Advanced Nursing 70(3):e3-5.

Atkin, D., Hunt, D., and. Lin. C. 2015. "Diffusion Theory in the New Media Environment: Towards an Integrated Technology Adoption Model." Mass Communication and Society 18(10):623-50.

Bianchi, M., Di Benedetto, A., Franzò, S., and Frattini, F. 2017. "Selecting Early Adopters to Foster the Diffusion of Innovations in Industrial Markets." European Journal of Innovation Management 20(4):620-44.

Bodle, A. 2016. "How New Words Are Born." The Guardian, February.

Choi, Jeong Ok and Unjong Yu. 2020. "Diffusion of Innovations in Finite Networks: Effects of Heterogeneity, Clustering, and Bilingual Option on the Threshold in the Contagion Game Model." Physica A: Statistical Mechanics and Its Applications 545.

Choudhury, M. De, Lin, Y. R., Sundaram, H., Candan, K. S., Xie, L., and Kelliher, A. 2010. "How Does the Data Sampling Strategy Impact the Discovery of Information Diffusion in Social Media?" ICWSM, 34-41.

Gaetan, V. 2019. “The Amazon Comes to Rome.” Foreign Affairs, November.

Glass, A. 2007. "Understanding Generational Differences for Competitive Success." Industrial and Commercial Training (39):98-103.

Hall, W., Tinati, R., and Jennings, W. 2018. "From Brexit to Trump: Social Media's Role in Democracy." Computer 51(1):18-27.

Helsper, E. and Enyon, R. 2009. “Digital Natives: Where Is the Evidence?” British Educational Research Journal 36(3):503-20. Hemsley, J., Garcia-Murillo, M., and Macinnes, I. 2018. "Tweets That Resonate:

Information Flows and the Growth of Twitter's Universal Basic Income Discussion Space." Policy and Internet 10(3):324-46.

Heng, C. Y. and Yazdanifard, R. 2013. "Generation Gap: Is There a Solid Solution?

From Human Relation Point of View." International Journal of Economy, Management and Social Sciences 2(10):837-40.

Iii, Ezequiel Silva. 2016. "Here Come the Baby Boomers." Journal of the American College of Radiology 13(3):242. 
Krohn, F. B. 2004. "A Generational Approach to Using Emoticons as Nonverbal Communication." Journal of Technical Writing and Communication 34(4):321-28.

Lee, J., Lee, Y., and Kim, S. 2019. "Loan Type and Debt Delinquency among Millennial and Non-Millennial Households." Family and Consumer Sciences Research Journal 47(4):342-58.

Lorenz, T. 2019. "OK Boomer' Marks the End of Friendly Generational Relations." The New York Times, October.

Loukis, E., Charalabidis, Y., and Androutsopoulou, A. 2017. "Promoting Open Innovation in the Public Sector through Social Media Monitoring." Government Information Quarterly 34(1):99-109.

Oehmichen, A., Hua, K., Amador Diaz Lopez, J., Molina-Solana, M., GomezRomero, J., and Guo, Y. 2019. "Not All Lies Are Equal. A Study Into the Engineering of Political Misinformation in the 2016 U.S. Presidential Election." IEEE Access (7):126305-126314.

Ohlheiser, A. 2019. "OK Boomer.” The Washington Post, November. Parment, Anders. 2013. "Generation Y vs. Baby Boomers: Shopping Behavior, Buyer Involvement and Implications for Retailing." Journal of Retailing and Consumer Services 20(2):189-99.

Phillipson, Chris, Rebecca Leach, Annemarie Money, and Simon Biggs. 2017. "Social and Cultural Constructions of Ageing : The Case of the Baby Boomers." 13(May 2008):1-14.

Riederer, R. 2019. "Climate Change Is the Ultimate 'OK, Boomer' Issue." The New Republic, December.

Rogers, E. 1962. The Diffusion of Innovations. New York: The Free Press of Glencoe Division of the Macmillan Company.

Ross, A., Todd, A., and Saedi, A. 2015. "Patient Seeking Behaviors and Online Personas: Social Media's Role in Cosmetic Dermatology." Dermatologic Surgery 41(2):269-76.

Schiavone, F. and Simoni, M. 2019. "Strategic Marketing Approaches for the Diffusion of Innovation in Highly Regulated Industrial Markets: The Value of Market Access." Journal of Business and Industrial Marketing 34(7):1606-18.

Srivastava, P. 2012. "Social Networking and Its Impact on Education-System in Contemporary Era." International Journal of Information Technology Infrastructure 1(2):11-18.

Taneja, Harsh, Angela Xiao Wu, and Stephanie Edgerly. 2018. "Rethinking the Generational Gap in Online News Use : An Infrastructural Perspective.” Media and Society 20(5):1972-1818. Turnbull, C. F. 2010. "Mom Just Facebooked Me and Dad Knows How to Text: 
The Influences of Computer-Mediated Communication on Interpersonal Communication and Differences through Generations." Elon Journal of Undergraduate Research in Communications (1):5-16.

Venter, Elza. 2017. "Bridging the Communication Gap between Generation Y and the Baby Boomer Generation Bridging the Communication Gap between Generation $\mathrm{Y}$ and the Baby Boomer Generation." International Journal of Adolescence and Youth 3843:1-11.

Wagner, K. and Gainous, J. 2009. "Electronic Grassroots: Does Online Campaigning Work?" The Journal of Legislative Studies 15(4):502-20.

Webster, JG. 2006. "Audience Flow Past and Present: Television Inheritance Effects Reconsidered." Journal of Broadcasting and Electronic Media 50(2):323-37.

Winston, Norma A., Jo Barnes, and Norma A. Winston. 2008. "Anticipation of Retirement Among Baby Boomers Anticipation of Retirement Among Baby Boomers." (October 2014):37-41.

Zhang, A., Zheng, M., and Pang, B. 2018. "Structural Diversity Effect on Hashtag Adoption in Twitter." Physica A: Statistical Mechanics and Its Applications 493:267-75. 